Article

\title{
The Chikungunya Virus Capsid Protein Contains Linear B Cell Epitopes in the $N$ - and $C$-Terminal Regions that are Dependent on an Intact $C$-Terminus for Antibody Recognition
}

\author{
Lucas Y. H. Goh ${ }^{1, \dagger}{ }^{\dagger}$ Jody Hobson-Peters ${ }^{1, \dagger}{ }^{\dagger}$ Natalie A. Prow ${ }^{1}$, Kelly Baker ${ }^{1}$, \\ Thisun B. H. Piyasena ${ }^{1}$, Carmel T. Taylor ${ }^{2}$, Ashok Rana ${ }^{3}$, Marcus L. Hastie ${ }^{3}$, Jeff J. Gorman ${ }^{3}$
} and Roy A. Hall ${ }^{1, *}$

${ }^{1}$ Australian Infectious Diseases Research Centre, School of Chemistry and Molecular Biosciences, The University of Queensland, St Lucia, Queensland 4072, Australia;

E-Mails: 1.goh1@uq.edu.au (L.Y.H.G.); j.peters2@uq.edu.au (J.H.-P.); natalie.prow@qimrberghofer.edu.au (N.A.P.); kelly.baker1@uqconnect.edu.au (K.B.); thisun.piyasena@uqconnect.edu.au (T.B.H.P.)

${ }^{2}$ Public Health Virology, Queensland Health Forensic and Scientific Services, Coopers Plain, Queensland 4108, Australia; E-Mail: carmel_taylor@health.qld.gov.au

${ }^{3}$ Protein Discovery Centre, QIMR Berghofer Medical Research Institute, Herston, Queensland 4029, Australia; E-Mails: ashok.rana@qimr.edu.au (A.R.); marcus.hastie@qimrberghofer.edu.au (M.L.H.); jeffrey.gorman@qimrberghofer.edu.au (J.J.G.)

$\dagger$ These authors contributed equally to this work.

* Author to whom correspondence should be addressed; E-Mail: roy.hall@uq.edu.au; Tel.: +61-73365-4647; Fax: +61-73365-4620.

Academic Editor: Curt Hagedorn

Received: 3 February 2015 / Accepted: 29 May 2015 / Published: 8 June 2015

\begin{abstract}
Chikungunya virus (CHIKV) is an arthropod-borne agent that causes severe arthritic disease in humans and is considered a serious health threat in areas where competent mosquito vectors are prevalent. CHIKV has recently been responsible for several millions of cases of disease, involving over 40 countries. The recent re-emergence of CHIKV and its potential threat to human health has stimulated interest in better understanding of the biology and pathogenesis of the virus, and requirement for improved treatment, prevention and control measures. In this study, we mapped the binding sites of a panel of eleven monoclonal antibodies (mAbs) previously generated towards the capsid protein $(\mathrm{CP})$ of CHIKV. Using
\end{abstract}


$N$ - and $C$-terminally truncated recombinant forms of the CHIKV CP, two putative binding regions, between residues 1-35 and 140-210, were identified. Competitive binding also revealed that five of the $\mathrm{CP}$-specific mAbs recognized a series of overlapping epitopes in the latter domain. We also identified a smaller, $N$-terminally truncated product of native $\mathrm{CP}$ that may represent an alternative translation product of the CHIKV 26S RNA and have potential functional significance during CHIKV replication. Our data also provides evidence that the $C$-terminus of $\mathrm{CP}$ is required for authentic antigenic structure of $\mathrm{CP}$. This study shows that these anti-CP mAbs will be valuable research tools for further investigating the structure and function of the CHIKV CP.

Keywords: chikungunya virus; monoclonal antibodies; capsid protein; epitope mapping; linear B cell epitope; $C$-terminus; $N$-terminus

\section{Introduction}

Alphaviruses are spherical, enveloped, positive-sense single-stranded RNA viruses responsible for several globally significant human and animal diseases. Alphavirus members include Sindbis virus (SINV), Semliki Forest virus (SFV), Ross River virus (RRV), the Western, Eastern and Venezuelan equine encephalitis viruses, as well as chikungunya virus (CHIKV), all of which are transmitted by mosquitoes. CHIKV infection is characterized by an onset of fever, headache, fatigue, nausea, myalgia and maculopapular rash, often followed by severe acute and/or chronic polyarthralgia [1-4]. Since its re-emergence in the early 2000s, CHIKV has been responsible for a succession of unprecedented outbreaks causing up to 6.5 million human infections in over 40 countries in East Africa, the Indian Ocean islands, several regions of South Asia, and most recently in Europe, Oceania and the Caribbean regions [1,5-11]. It has also been recently associated with severe disease manifestations, and mortality in some cases, largely amongst elderly patients with co-morbidities and the very young [12-15].

Similar to other alphaviruses, CHIKV has a $\sim 11.5 \mathrm{~kb}$ RNA genome that is capped at its $5^{\prime}$ end and polyadenylated at its $3^{\prime}$ end. The genome encodes four non-structural proteins, nsP1 to nsP4, and five structural proteins: capsid, E3, E2, 6K and E1 [16]. Studies have shown that the alphavirus capsid protein $(\mathrm{CP})$ is multifunctional and plays a crucial role in the assembly and budding of alphaviruses. It is capable of self-cleavage prior to the recognition and binding of genomic RNA [17]. Apart from its primary role of forming the nucleocapsid, the $\mathrm{CP}$ has been shown to have inhibitive and/or regulative functions in regard to viral replication, as well as host and viral protein synthesis $[18,19]$. The CP of alphaviruses, as described in a SINV model, is organized into three separate regions-I, II and III—each with their respective functions [20]. As shown in Figure 1, the unconserved $N$-terminal domain of the alphavirus CP has a high degree of positive charge implicated in non-specific RNA binding, while the highly-conserved $C$-terminal region harbours a globular chemotrypsin-like serine protease and contains the binding site for the spike protein. A recent study by Thomas et al. [21] has also identified functional nuclear localization and export signals (NLS/NES) within the CHIKV CP. Furthermore, previous reports on the discovery of nucleolar targeting signals in SFV CP suggest that these signals are responsible for the karyophilic properties of the protein [22-24]. NLS sequences in forms of synthetic peptides 
have been used to demonstrate efficient transport of the $\mathrm{CP}$ into the nucleus of both higher and lower eukaryotic target cells [22]. Nonetheless, a functional role has yet to be attributed to this putative intracellular transport of the $\mathrm{CP}$ during infection.

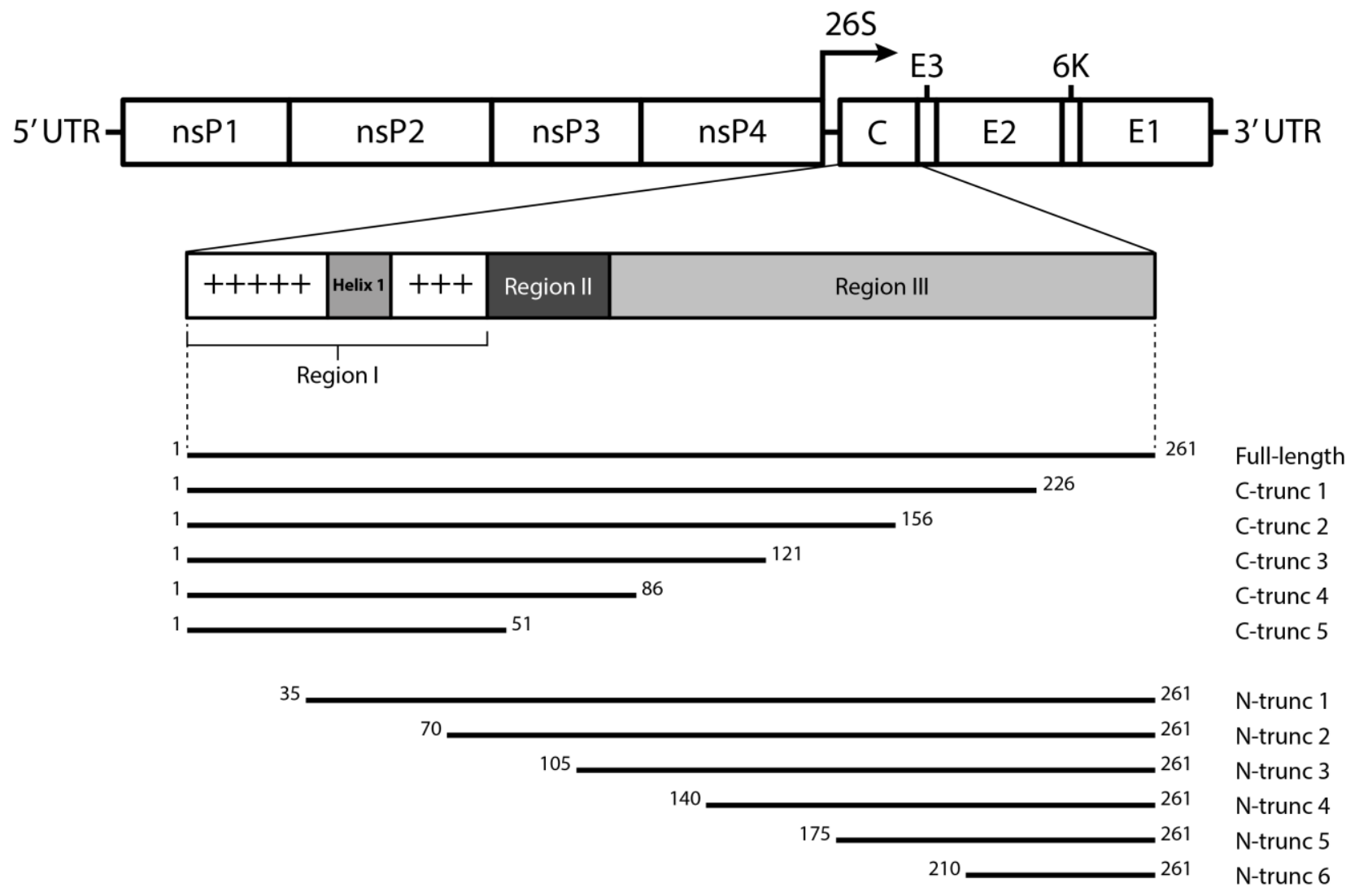

Figure 1. Schematic representation of the alphavirus capsid protein $(\mathrm{CP})$ and the design of $N$ - and $C$-terminal truncations in recombinant chikungunya virus (CHIKV) CP. The alphavirus $\mathrm{CP}$ is segmented into three separate regions, based on the prototype Sindbis virus (SINV) CP model-adapted from Hong et al. [20]. Region I has a high degree of positive charge associated with non-specific binding of the genomic viral RNA. Located within the same region, Helix 1, a sequence of uncharged amino acids, is suggested to be involved in the interactions during nucleocapsid core formation and its stabilization. Region II contains the minimum sequence required for specific RNA binding, while the $C$-terminal protease domain (region III) forms capsomeres in the nucleocapsid core and interacts with the E2 glycoprotein. The bottom part of the figure depicts the locations of the $C$ - or $N$-terminal truncations within the full-length CP. Truncations were made in 35-amino acid increments.

The $\mathrm{CP}$ is a critical component of the assembly of alphaviruses. To date, alphaviral CP research is mainly based on models of SINV and SFV, and exact roles and/or functions of the CHIKV CP has largely been assumed to be similar to that of its closely-related viruses. However, the re-emergence of CHIKV and its potential threat to human health has demanded a more detailed understanding of the virus. Herein we report the use of a series of truncated recombinant proteins derived from the CHIKV CP, mass spec analysis of native CHIKV CP and competitive binding studies to map the binding sites of a panel of 
eleven monoclonal antibodies (mAbs) to antigenic domains at the $N$-terminal region and the $C$-terminal half of the protein.

\section{Material and Methods}

\subsection{Cell and Virus Culture}

C6/36 (Aedes albopictus mosquito) cells were propagated in RPMI 1640 supplemented with 2\% fetal bovine serum. Cultures were passaged by dissociating the cell monolayer from the flask with trypsin/PBS and were incubated at $28{ }^{\circ} \mathrm{C}$. Vero and COS-7L (African green monkey kidney) cell lines were cultured in DMEM and RPMI 1640, respectively, supplemented with 5\% fetal bovine serum (FBS) during proliferation and 2\% FBS for maintenance. Mammalian cells were passaged by dissociating the surface monolayer from the flask with trypsin/EDTA and were cultured at $37{ }^{\circ} \mathrm{C}$ with $5 \% \mathrm{CO}_{2}$. Hybridoma cells were expanded in Hybridoma SFM (Gibco, Life Technologies, Carlsbad, CA, USA) with $20 \% \mathrm{FBS}$ at $37{ }^{\circ} \mathrm{C}$ with $5 \% \mathrm{CO}_{2}$, before being weaned off all FBS for the harvesting of mAbs in culture fluid. All cell cultures were supplemented with $50 \mathrm{U}$ penicillin $\mathrm{mL}^{-1}, 50 \mu \mathrm{g}$ streptomycin $\mathrm{mL}^{-1}$ and $2 \mathrm{mM}$ L-Glutamine (Gibco, Life Technologies).

Viruses used for the infection of $\mathrm{C} 6 / 36$ cells included CHIKV Mauritius strain (CHIKV $\mathrm{CAU}_{\text {) }}$ (GenBank ID: EU404186) and RRV T48 strain ( $\left.\mathrm{RRV}_{\mathrm{T} 48}\right)$ (GenBank ID: GQ433359). For harvesting of virus stocks, cells were infected at an M.O.I. of 0.1 for $1 \mathrm{~h}$, washed thrice with PBS and incubated for a further $48-72 \mathrm{~h}$ before culture supernatants were clarified by centrifugation at $12,000 \times g$ for 10 min at $4{ }^{\circ} \mathrm{C}$ and stored at $-80{ }^{\circ} \mathrm{C}$. To obtain crude cell lysates, mock and/or virus-infected C6/36 cell monolayers were incubated in a similar manner before cells were rinsed in PBS and disrupted by sonication in the presence of BS9 lysis buffer $\left(120 \mathrm{mM} \mathrm{NaCl}, 50 \mathrm{mM} \mathrm{H}_{3} \mathrm{BO}_{3}, 1 \%\right.$ Triton X-100 and $0.1 \%$ SDS, $\mathrm{pH}$ 9.0). Lysates were clarified as mentioned above and stored at $-20{ }^{\circ} \mathrm{C}$ [25].

\subsection{Cloning and Expression of CHIKV CP Truncations}

CHIKV CP truncation constructs (Figure 1, bottom) were generated by amplifying the respective CP gene sequences from cDNA synthesized by reverse-transcription PCR of genomic RNA of CHIKV $\mathrm{V}_{\mathrm{MAU}}$, either by pairing the CHIKV Capsid Forward PCDNA primer with one of the CHIKV Capsid N1-6 Reverse PCDNA primers, or the CHIKV Capsid Reverse PCDNA primer with one of the CHIKV Capsid C1-5 Forward PCDNA primers (Table 1). Following that, inserts were ligated into a pcDNA3.1 (+) vector (Invitrogen) modified to express V5 and histidine tags at the $C$-terminus of the recombinant proteins. COS-7L cell transfection was performed using Lipofectamine 2000 (Invitrogen) according to manufacturer's instructions. Cells were harvested $48 \mathrm{~h}$ post-transfection by addition of BS9 lysis buffer and clarified by centrifugation [26]. 
Table 1. Nucleotide sequences of CHIKV capsid truncation primers.

\begin{tabular}{cccc}
\hline Primer code & Sequence $\left(\mathbf{5}^{\prime}\right.$ to $\left.\mathbf{3}^{\prime}\right)$ & Tm $\left({ }^{\circ} \mathbf{C}\right)$ & Expected size $(\mathbf{b p})$ \\
\hline CHIKV Capsid F PCDNA & TATATAGCTAGCATGGAGTTCATCCCAACCCAA & 76.7 & - \\
CHIKV Capsid N1 R PCDNA & TATATAGGATCCGGCCACCACGCGTCCCT & 72.3 & 678 \\
CHIKV Capsid N2 R PCDNA & TATATAGGATCCGTGGTGCCAGTTGTAGTAC & 55.3 & 573 \\
CHIKV Capsid N3 R PCDNA & TATATAGGATCCCCGCTTAAAGGCCAGTTT & 61.7 & 468 \\
CHIKV Capsid N4 R PCDNA & TATATAGGATCCACCTTCGTGCTTGACTTC & 57.8 & 363 \\
CHIKV Capsid N5 R PCDNA & TATATAGGATCCCTGCTTCTTTTGATTTGTG & 55.9 & 258 \\
CHIKV Capsid N6 R PCDNA & TATATAGGATCCCAGTTTATTAACTGCTGAGATC & 55.3 & 153 \\
CHIKV Capsid R PCDNA & TATATAGGATCCACTCCACTCTTCGGCCCC & 74.8 & - \\
CHIKV Capsid C1 F PCDNA & TATATAGCTAGCATGAGGCAAGCTGGGCAAC & 67.6 & 678 \\
CHIKV Capsid C2 F PCDNA & TATATAGCTAGCATGAAGCAAAAACAACAGGC & 74.8 & 573 \\
CHIKV Capsid C3 F PCDNA & TATATAGCTAGCATGTGCATGAAAATCGAAAAT & 60.7 & 468 \\
CHIKV Capsid C4 F PCDNA & TATATAGCTAGCATGAAGGGGACCATCGATAA & 67.7 & 363 \\
CHIKV Capsid C5 F PCDNA & TATATAGCTAGCATGTCGAAGTTCACCCATGA & 65.6 & 258 \\
\hline
\end{tabular}

\subsection{Immunofluorescence Assay (IFA)}

Transfected COS-7L cells were fixed onto glass coverslips with $100 \%$ ice-cold acetone and incubated with selected mAbs in hybridoma culture fluid at a $1 / 20$ dilution for $1 \mathrm{~h}$ at $37{ }^{\circ} \mathrm{C}$. Coverslips were then washed and stained with Alexa Fluor 488-conjugated goat anti-mouse IgG (Invitrogen, Carlsbad, CA, USA) diluted 1:500 in blocking buffer (5\% BSA in PBS) for $1 \mathrm{~h}$ at $37{ }^{\circ} \mathrm{C}$, followed by Hoechst 33,342 stain (1:1000 in PBS, Invitrogen) for 5 min. Coverslips were mounted with ProLong Gold Anti-Fade reagent (Invitrogen) and imaged using a Zeiss LSM 510 META confocal microscope (Carl Zeiss AG, Oberkochen, Germany).

\subsection{Western/Dot Blot}

CHIKV antigens were prepared as transfected COS-7L cell lysates as described by Setoh et al. [27]. Reduction and carboxymethylation of antigens were carried out as previously described [28]. Briefly, lysates were diluted in Tris- $\mathrm{HCl}$ and reduced with $10 \mathrm{mM}$ dithiothreitol (DTT). Samples were then degassed with streaming nitrogen and heated to $95{ }^{\circ} \mathrm{C}$. The reduced lysates were cooled and iodoacetic acid was added before being subjected to a second round of degassing, followed by incubation at $37{ }^{\circ} \mathrm{C}$ in the dark. Antigens that were to be resolved on 4\%-12\% Bis-Tris precast SDS-PAGE gels (Invitrogen), were prepared in $4 \times$ NuPAGE LDS sample buffer (Invitrogen) and heated to $95{ }^{\circ} \mathrm{C}$ for 5 min prior to electrophoresis. The separated proteins were then transferred onto Hybond $\mathrm{C}$ nitrocellulose membranes (Amersham) and immune-stained as previously described [25]. For dot-blotting, treated or untreated antigen samples were carefully spotted directly onto Hybond $\mathrm{C}$ nitrocellulose membranes and allowed to dry for 5-10 min. Membranes were then blocked with TENTC blocking buffer (0.05 M Tris-HCl pH 8.0, $1 \mathrm{mM}$ EDTA, $0.15 \mathrm{M} \mathrm{NaCl}, 0.05 \%(v / v)$ Tween 20, $0.2 \%(w / v)$ casein) for $1 \mathrm{~h}$ at room temperature prior to the addition of primary antibodies diluted 1/20, unless otherwise stated, in blocking buffer. After incubation for another hour, membranes were washed thrice with $0.1 \%$ Tween-20 in PBS (PBS/T wash buffer) and bound antibodies were detected with a HRP-conjugated goat anti-mouse IgG diluted 1:4000 
in blocking buffer. The blots were incubated for a further $1 \mathrm{~h}$ before being washed three times with PBS/T wash buffer. Finally, blots were developed in DAB substrate solution (1.5 mM 3,3'-diaminobenzidine, $0.06 \%(v / v) \mathrm{H}_{2} \mathrm{O}_{2}$ in PBS, $\mathrm{pH}$ 7.2) for 15 min before reactions were terminated by rinsing with PBS or $\mathrm{ddH}_{2} \mathrm{O}$.

\subsection{Competitive Binding Enzyme-Linked Immunosorbent Assay (ELISA)}

Competitive binding between anti-CHIKV CP mAbs were assessed as described previously [29]. Briefly, purified mAbs were biotinylated using the BiotinTag kit (Sigma-Aldrich, St. Louis, MO, USA), according to manufacturer's instructions. Competitive binding ELISAs were performed in 96 well plates coated with lysates of $\mathrm{CHIKV}_{\mathrm{MAU}}$-infected $\mathrm{C} 6 / 36$ cells diluted $1 / 500$ in coating buffer $(0.05 \mathrm{M}$ sodium carbonate/bicarbonate, $\mathrm{pH}$ 9.6). After washing, a pre-defined optimal saturating concentration of each of the unlabelled mAbs was added for $1 \mathrm{~h}$ at $28{ }^{\circ} \mathrm{C}$. Without washing, a pre-defined optimal non-saturating dilution of each biotin-labelled 'competitor' $\mathrm{mAb}(40 \mathrm{ng} / \mathrm{mL})$ was added for $1 \mathrm{~h}$ at $28^{\circ} \mathrm{C}$. After washing six times with PBS/T, horseradish peroxidase (HRP)-conjugated streptavidin (Invitrogen) was added and incubated for $30 \mathrm{~min}$. The wells were washed prior to incubation with ABTS substrate solution. Uninfected C6/36 cell lysates were used as coating antigen to determine background cut-off values, while $4 \mathrm{G} 2$, a pan-reactive mAb targeting the flavivirus envelope protein, was used as the negative antibody control.

\subsection{Assessing Reactivity of mAbs to Synthetic Peptides}

A series of 20-mer peptides, with 10-residue overlaps, encompassing the entire CHIKV CP were designed (Table 2) and commercially synthesized (Mocell Biotech, Hong Kong). Each peptide was coupled to carboxylated polystyrene beads using the Bio-Plex amine coupling kit (Bio-Rad, Hercules, CA, USA) according to the manufacturer's instructions. The coupled beads were then multiplexed by diluting in microsphere immunoassay (MIA) buffer (1\% BSA, 0.05\% ProClin 300 (Supelco, Bellefonte PA, USA) in PBS) and distributed to give approximately 2500 of each beadset ( $100 \mu \mathrm{L})$ per well of a MultiScreen filter plate (Merck Millipore, Billerica, MA, USA). Each anti-CHIKV CP mAb was then tested against the multiplexed beadsets by incubation for $45 \mathrm{~min}$ with shaking at room temperature. The wells were then washed three times with PBS/T wash buffer, prior to the addition of R-Phycoerythrin donkey anti-mouse IgG (Jackson ImmunoResearch, West Grove, PA, USA). Following that, the wells were incubated and washed as previously, after which the beads were resuspended in MIA buffer. The Bio-Plex 200 (Luminex, Bio-Rad, Austin, TX, USA) was then utilized to read the plate, measuring the mean fluorescence intensity for each beadset in their respective wells. mAb recognition of peptides was also assessed by ELISA and dot blot as previously described [29]. 
Table 2. Reactivity of mAbs to synthetic peptides.

\begin{tabular}{|c|c|c|c|c|c|c|c|}
\hline No. & Sequence & Length & Protein * & Position & MIA & ELISA & Dot Blot \\
\hline 1. & MEFIPTQTFYNRRYQPRPWT & 20 & CHIKV CP & $1-20$ & - & - & - \\
\hline 2. & NRRYQPRPWTPRPTIQVIRP & 20 & CHIKV CP & $11-30$ & - & - & - \\
\hline 3. & PRPTIQVIRPRPRPQRQAGQ & 20 & CHIKV CP & $21-40$ & - & - & - \\
\hline 4. & RPRPQRQAGQLAQLISAVNK & 20 & CHIKV CP & $31-50$ & - & - & - \\
\hline 5. & LAQLISAVNKLTMRAVPQQK & 20 & CHIKV CP & $41-60$ & - & - & - \\
\hline 6. & LTMRAVPQQKPRRNRKNKKQ & 20 & CHIKV CP & $51-70$ & - & - & - \\
\hline 7. & PRRNRKNKKQKQKQQAPQNN & 20 & CHIKV CP & $61-80$ & - & - & - \\
\hline 8. & KQKQQAPQNNTNQKKQPPKK & 20 & CHIKV CP & $71-90$ & - & - & - \\
\hline 9. & TNQKKQPPKKKPAQKKKKPG & 20 & CHIKV CP & $81-100$ & - & - & - \\
\hline 10. & KPAQKKKKPGRRERMCMKIE & 20 & CHIKV CP & $91-110$ & - & - & - \\
\hline 11. & RRERMCMKIENDCIFEVKHE & 20 & CHIKV CP & $101-120$ & - & - & - \\
\hline 12. & NDCIFEVKHEGKVTGYACLV & 20 & CHIKV CP & $111-130$ & - & - & - \\
\hline 13. & GKVTGYACLVGDKVMKPAHV & 20 & CHIKV CP & $121-140$ & - & - & - \\
\hline 14. & GDKVMKPAHVKGTIDNADLA & 20 & CHIKV CP & $131-150$ & - & - & - \\
\hline 15. & KGTIDNADLAKLAFKRSSKY & 20 & CHIKV CP & $141-160$ & - & - & - \\
\hline 16. & KLAFKRSSKYDLECAQIPVH & 20 & CHIKV CP & $151-170$ & - & - & - \\
\hline 17. & DLECAQIPVHMKSDASKFTH & 20 & CHIKV CP & $161-180$ & - & - & - \\
\hline 18. & MKSDASKFTHEKPEGYYNWH & 20 & CHIKV CP & $171-190$ & - & - & - \\
\hline 19. & EKPEGYYNWHHGAVQYSGGR & 20 & CHIKV CP & $181-200$ & - & - & - \\
\hline 20. & HGAVQYSGGRFTIPTGAGKP & 20 & CHIKV CP & $191-210$ & - & - & - \\
\hline 21. & FTIPTGAGKPGDSGRPIFDN & 20 & CHIKV CP & $201-220$ & - & - & - \\
\hline 22. & GDSGRPIFDNKGRVVAIVLG & 20 & CHIKV CP & $211-230$ & - & - & - \\
\hline 23. & KGRVVAIVLGGANEGARTAL & 20 & CHIKV CP & $221-240$ & - & - & - \\
\hline 24. & GANEGARTALSVVTWNKDIV & 20 & CHIKV CP & $231-250$ & - & - & - \\
\hline 25. & SVVTWNKDIVTKITPEGAEEW & 21 & CHIKV CP & $241-261$ & - & - & - \\
\hline 26. & SAAKHARKERNITGGHPVSR & 20 & $\mathrm{WNV}_{\mathrm{KUN}} \mathrm{NS5}$ & $38-57$ & + & + & + \\
\hline 27. & CTTVESHGNYSTQVGATQAG & 20 & $\mathrm{WNV}_{\text {NY99 }} \mathrm{E}$ & $146-165$ & + & + & + \\
\hline 28. & Full-length CHIKV CP & 261 & CHIKV CP & N/A & ${ }^{\#} \mathrm{ND}$ & + & + \\
\hline
\end{tabular}

* Each synthetic peptides was screened against all eleven anti-CHIKV CP mAbs, polyclonal anti-CHIKV antibodies, as well as 5H1 (anti-WNV $\mathrm{KUN}_{\mathrm{KU}} \alpha 3$ ) and 17D7 (anti-WNV $\mathrm{WY}_{\mathrm{N} 9} \mathrm{E}$ ) [29,30]; A “+” result represents reactivity with the peptide's respective control $\mathrm{mAb}$; ${ }^{\#} \mathrm{ND}=$ not determined; $\mathrm{MIA}=$ microsphere immunoassay; Full-length CHIKV CP was reactive towards all eleven anti-CHIKV CP mAbs and polyclonal anti-CHIKV antibodies in ELISA and dot blot.

\subsection{Immunoprecipitation of CHIKV CP}

Protein pull-downs were performed on clarified lysates of $\mathrm{CHIKV}_{\mathrm{MAU}}$-infected $\mathrm{C} 6 / 36$ cells using Dynabeads Protein G (Novex, Life Technologies) according to manufacturer's instructions. Boiled and/or reduced samples were then resolved via SDS-PAGE as described above (see Section 2.4) prior to incubation of the gel in Coomassie blue stain (1\% (w/v) Coomassie R250, $10 \%$ glacial acetic acid, 40\% methanol in $\mathrm{ddH}_{2} \mathrm{O}$ ) at room temperature for 30 min before being rinsed twice with destaining solution (10\% glacial acetic acid, $40 \%$ methanol in $\mathrm{ddH}_{2} \mathrm{O}$ ). The gel was then incubated in destaining solution overnight with rocking. 


\subsection{Mass Spectrometry Analysis}

Individually stained bands were excised, reduced, alkylated and subjected to in-gel tryptic digestion as described in detail previously [31]. Acidified digests were subjected to NanoHPLC-MS/MS analysis using a nanoAcquity nanoHPLC system (Waters, Milford, MA, USA) interfaced with a linear ion-trap (LTQ)-Orbitrap Elite hybrid mass spectrometer (Thermo Fischer Scientific, Bremen, Germany). Digests were loaded onto a $5 \mu \mathrm{m}$ Symmetry $180 \mu \mathrm{m} \times 20 \mathrm{~mm} \mathrm{C18}$ trap column (Waters) at $15 \mu \mathrm{L} / \mathrm{min}$ in $98 \%$ solvent $\mathrm{A}(0.1 \%(\mathrm{v} / \mathrm{v})$ aqueous formic acid $)$ and $2 \%$ solvent $\mathrm{B}(0.1 \%(\mathrm{v} / \mathrm{v})$ formic acid in $100 \%$ acetonitrile) for $3 \mathrm{~min}$ at $22{ }^{\circ} \mathrm{C}$ then switched in-line with a pre-equilibrated analytical column (BEH130 C18 $1.7 \mu \mathrm{m}, 75 \mu \mathrm{m} \times 200 \mathrm{~mm}$, Waters) at a flow rate of $0.3 \mu \mathrm{L} / \mathrm{min}$ and $98 \%$ solvent $\mathrm{A}, 2 \%$ solvent B. Peptides were separated at $35{ }^{\circ} \mathrm{C}$ using a sequence of linear gradients: starting from $5 \% \mathrm{~B}$ over $1 \mathrm{~min}$, to $40 \%$ B over $29 \mathrm{~min}$, and finally, to $95 \%$ B over $4 \mathrm{~min}$, before holding the column at $95 \%$ $\mathrm{B}$ for a further $4 \mathrm{~min}$. Eluates from the analytical column were then introduced into the LTQ-Orbitrap Elite throughout the entire run via a Nanospray Flex Ion Source (Thermo Fisher Scientific) containing a $10 \mu \mathrm{m}$ P200P coated silica emitter (New Objective). Typical spray voltage was $1.8 \mathrm{kV}$ with no sheath, sweep or auxiliary gases; heated capillary temperature was set to $275^{\circ} \mathrm{C}$. The LTQ-Orbitrap Elite was controlled using Xcalibur 2.2 SP1.48 software (Thermo Fisher Scientific) and operated in a data-dependent acquisition mode to automatically switch between Orbitrap-MS and ion trap-MS/MS. The survey full scan mass spectra (from $\mathrm{m} / \mathrm{z}$ 380-1700) were acquired in the Orbitrap with a resolving power of 120,000 after accumulating ions to an automatic gain control (AGC) target value of $1.0 \times 10^{6}$ charges in the LTQ. MS/MS spectra were concurrently acquired in the LTQ on the 20 most intense ions from the survey scan, using an AGC target value of $1.0 \times 10^{4}$. Charge state filtering, where unassigned precursors and singly charged ions were not selected for fragmentation, and dynamic exclusion (repeat count 1 , repeat duration $30 \mathrm{~s}$, exclusion list size 500, exclusion duration $30 \mathrm{~s}$ ) were used. Fragmentation conditions in the LTQ were: $35 \%$ normalized collision energy, activation q of $0.25,10 \mathrm{~ms}$ activation time, and minimum ion selection intensity of 500 counts. Maximum ion injection times were $250 \mathrm{~ms}$ and $100 \mathrm{~ms}$ for survey full scans and MS/MS scans, respectively.

\subsection{Data Analysis}

Tandem mass spectra were processed using Proteome Discoverer (version 1.4, Thermo Fisher Scientific, San José, CA, USA) and submitted to Mascot (version 2.5.1, Matrix Science, London, UK). Fixed modification: carbamidomethyl-cysteine; variable modifications: deamidation (asparagine, glutamine) and oxidation (methionine). Enzyme: trypsin, 2 missed cleavages; MS tolerance 20 ppm; MSMS tolerance 0.6 Da using a database downloaded from UniprotKB on the 21 July 2014 consisting of the reference proteome for Aedes aegypti (UP000008820), chikungunya virus (strain 37997) (UP000008450), reference proteome chikungunya virus (strain S27-African prototype) with the sequence of the capsid protein added as a separate entry. Scaffold (4.4.1.1, Proteome Software, Portland, OR, USA, 2014) was used to validate Mascot protein identifications [32]. Scaffold probabilistically validates these peptide identifications using PeptideProphet [33]. A cut-off of $99 \%+2,+3$ and 5 ppm error was used to validate the peptides. 


\section{Results}

\subsection{Anti-CHIKV CP mAbs Recognize Linear Epitopes}

To determine whether a panel of eleven anti-CHIKV CP mAbs bound conformational or linear epitopes, antigens in the form of crude lysates derived from CHIKV-infected C6/36 cells were subjected to reduction with DTT and carboxymethylation of their free sulfhydryl groups so as to prevent the reformation of disulfide bonds. These antigens were separated by SDS-PAGE alongside boiled, unreduced, or boiled, reduced, uncarboxymethylated lysates prior to immunoblotting. Probing with each of the CP-specific mAbs, including representative antibody 1.7B2 (Figure 2), revealed that all eleven antibodies recognized $\mathrm{CP}$ under both unreduced $(\sim 34 \mathrm{kDa})$ and reduced $(\sim 35 \mathrm{kDa})$ conditions, even after carboxymethylation $(\sim 37 \mathrm{kDa})$, indicating that the anti-CHIKV CP mAbs recognized linear epitopes that are not dependent on disulfide bonds to provide secondary structure. The increase in molecular weight with each treatment is an indication of successful chemical modification due to the thiol-disulfide exchange during reduction and the addition of iodoacetic acid during S-carboxymethylation of cysteine residues within the CP.

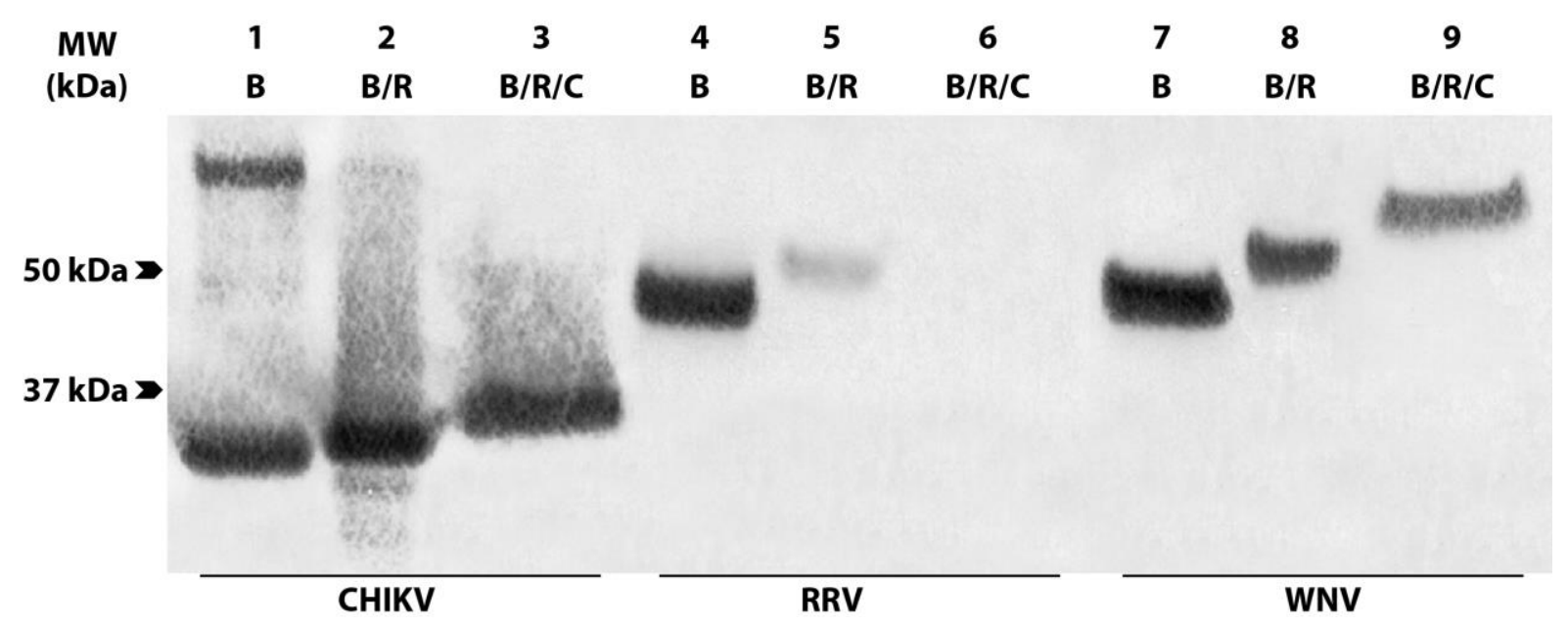

Figure 2. Reactivity of anti-CHIKV CP mAbs against boiled, reduced and/or carboxymethylated CHIKV cell lysates. Boiled (B), boiled and reduced (B/R) or boiled, reduced and carboxymethylated (B/R/C) lysates of CHIKV (lanes 1-3), RRV (lanes 4-6) and West Nile virus (lanes 7-9) were probed with antibodies 1.7B2 (anti-CP), RRG8 (anti-E1) and 17D7 (anti-E), respectively, in Western blot. RRV and West Nile virus lysates were included as controls to illustrate binding of reference antibodies known to recognize conformational (RRG8) and linear epitopes (17D7) respectively.

Since the Western blot results indicated that all anti-CP mAbs recognized linear epitopes, we designed a series of 20-mer synthetic peptides, with 10-residue overlaps, spanning the entire CHIKV CP to fine-map the epitopes of the anti-CHIKV mAbs. However, none of the mAbs showed any reactivity towards the synthetic peptides in ELISA, dot blot or in MIA, despite the successful detection of all control peptides by their corresponding reference mAbs using these assays (see Table 2). This surprising result suggested that the binding of the $\mathrm{CP}$-specific $\mathrm{mAbs}$ may require additional structure provided by post-translational modifications not found in synthetic peptides. 
We have previously shown that these mAbs react with $\mathrm{CP}$ treated with PNGase F, indicating that $N$-linked glycosylation is not required, consistent with the absence of an $N$-linked glycosylation site and the cytoplasmic location of the protein [34]. Further analysis of the CHIKV CP sequence using a prediction software, NetPhos 2.0 [35], revealed the presence of several potential phosphorylation sites that may participate in the structure of epitope(s) recognized by these mAbs (Figure 3). However, attempts to demonstrate this by dephosphorylation of CHIKV CP prior to analysis by Western blot were inconclusive.

\begin{tabular}{|c|c|c|}
\hline RRVT 48 & MNYI PTQTFYGRRWRPRP-AFRPWQVPMQPTPTMVTPMLQAPDLQAQQMQQLISAVSALT & 59 \\
\hline SFV & MNYIPTQTFYGRRWRPRP-AARPW--PLQATP--VAPVV--PDFQAQQMQQLISAVNALT & 53 \\
\hline CHIKVMAU & MEFIPTQTFYNRRYQPRPWIPRPTIQVIRPRPR--------PQRQAGQLAQLISAVNKLT & 52 \\
\hline BEV & MDFI PTQTFYGRRWRPAP-VQRYI PQPQPPAPP-------RRRRGPSQLQQLVAALGALA & 52 \\
\hline \multirow[t]{2}{*}{ SINVMRE16 } & MNRG-FFNMLGRRPFPAPTSMWRPRRRRQAAPG------PARNGLATQIQQLTSAVNALV & 53 \\
\hline & 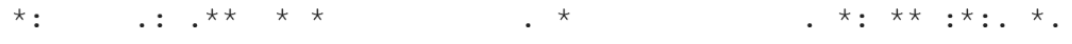 & \\
\hline RRVT 48 & TKQNVKAPKGQRK-KKQQKPKEKKENQKKKPTQKKKQQQKPKPQA--KKKKPGRRERMCM & \\
\hline SFV & MRQNAIAPARPPKPKKKKTTKPKPKTQPKKINGKTQQQKKKDKQADKKKKKPGKRERMCM & \\
\hline CHIKVMAU & MR--AVPQQKPRRNRKNKKQKQKQQAPQNNTNQKKQPPKKKPAQK---KKKPGRRERMCM & 07 \\
\hline BFV & LQPKQKQKRAQKKPKKTPPPKPKKTQKPKKPTQKK-------------KSKPGKRMRNCM & \\
\hline \multirow[t]{2}{*}{ SINVMRE1 6} & IGQVSRQQQPRQRPAPKPRRQPPKQQQPKPKKTKNPEKPKKKQPT---KPKPGKRQRMAL & \\
\hline & $\begin{array}{lll}: & : & :\end{array}$ & \\
\hline RRVT 48 & KIENDCIFEVKLDG-KVTGYACLVGDKVMKPAHVKGTIDNPDLAKLTYKKSSKYDLECAQ & \\
\hline SFV & KIENDCIFEVKHEG-KVTGYACLVGDKVMKPAHVKGVIDNADLAKLAFKKSSKYDLECAQ & 72 \\
\hline CHIKVMAU & KIENDCIFEVKHEG-KVTGYACLVGDKVMKPAHVKGTIDNADLAKLAFKRSSKKYDLECAQ & \\
\hline $\mathrm{BFV}$ & KIENDCIFPVMLDG-KVNGYACLVGDKVMKPAHVKGT IDNPELAKLTFKKSSKYDLECAQ & \\
\hline \multirow[t]{2}{*}{ SINVMRE16 } & KLEADRLFDVKNEAGEVIGHALAMEGKVMKPLHVKGTIDHPVLSKLKFTKSSAYDMEFAQ & \\
\hline & 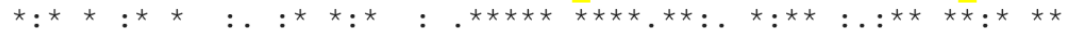 & \\
\hline RRVT 48 & IPVHMKSDASKYTHEKPEGHYNWHHGAVQYSGGRFTIPTGAGKPGDSGRPI FDNKGRVVA & \\
\hline SFV & IPVHMRSDASKYTHEKPEGHYNWHHGAVQYSGGRFTIPTGAGKPGDSGRPI FDNKGRVVA & \\
\hline CHIKVMAU & IPVHMKSDASKFTHEKPEGYYNWHHGAVQYSGGRFTIPTGAGKPGDSGRPI FDNKGRVVA & \\
\hline BFV & VPVCMKSDASKFTHEKPEGHYNWHHGAVQFSNGETIPTGSGKPGDSGRPI FDNTGKVVA & \\
\hline \multirow[t]{2}{*}{ SINVMRE1 6} & LPTNMRSEAFSYTSEHPEGFYNWHHGAVQYSGGRFTVPKGAGGKGDSGRPIMDNTGKVVA & \\
\hline & 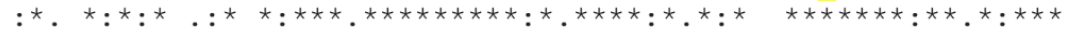 & \\
\hline RRVT 48 & IVLGGANEGARTALSVVTWT-KDMVTRVTPEGTEEW 270 & \\
\hline SFV & IVLGGANEGSRTALSVVTWN-KDMVTRVTPEGSEEW 267 & \\
\hline CHIKVMAU & IVLGGANEGARTALSVVTWN-KDIVTKIMPEGAEEW 261 & \\
\hline BFV & IVLGGANEGARTALSVVTWN-KDMVTRITPEESVEW 253 & \\
\hline \multirow[t]{2}{*}{ SINVMRE1 6} & IVLGGADEGARTALSVVTWNSKGKTIKTTPEGTEEW 266 & \\
\hline & 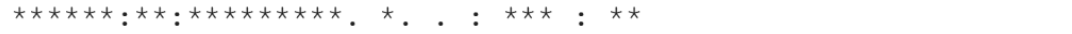 & \\
\hline
\end{tabular}

Figure 3. Capsid protein amino acid sequence alignment of closely-related alphaviruses. Asterisks (*), colons (:) and periods (.) indicate identical, conserved or semi-conserved substitutions, respectively. Residues highlighted in red represent potential phosphorylation sites predicted by NetPhos 2.0 (http://www.cbs.dtu.dk/services/NetPhos/), while yellow residues mark the conserved catalytic triad residues involved in the auto-proteolytic function of the CP. The teal-coloured tryptophan (position 261) is where the auto-cleavage occurs. Contributing amino acids of the predicted functional nuclear localization and export signals (NLS/NES) sequences are highlighted in green and blue, respectively. Red, bolded residues of the NES denote hydrophobic positions, indicating its similarity towards a non-classical NES sequence (Thomas et al., 2013). The methionine (position 105) highlighted in magenta indicates the potential alternative translation initiation site of the $N$-terminally truncated form of CP. Putative mAb binding domains are in bold (group 1 mAbs: 157-175; group 2 mAbs: 1-35). 


\subsection{Expression of $N$ - and $C$-terminally Truncated $C H I K V C P$}

In another approach to map the epitope(s) recognized by the anti-CP mAbs, recombinant full-length and a series of $N$ - and $C$-terminally truncated CP sequences (Figure 1) were expressed in COS-7L cells. Successful expression of full length and truncated proteins $C$-terminally fused to a V5-His tag, was confirmed by detection with anti-V5 mAb in IFA (Figure 4, Figure S1). Most of the truncations were also recognized by anti-V5 mAb in Western blot (Figure 5, Figure S2), although the smaller protein bands were not successfully transferred to the nitrocellulose membrane due to limitation of the membrane pore size.

To identify the binding regions of these mAbs in $\mathrm{CP}$, each antibody was subjected to Western blot analysis against each of the twelve truncated versions of CHIKV CP. Monoclonal antibodies 1.7B2, 4.1H11, 5.2H7, 5.5D11 and 5.5G9 (designated group 1), reacted with a series of the $N$-truncations (N1-4), as well as the full-length protein ( $\mathrm{rCp}$ ) (Table 3). This demonstrated that group $1 \mathrm{mAbs}$ still recognized $\mathrm{CP}$ in the absence of the first 140 residues (see Figure 1) suggesting the epitope(s) they recognize resides in the $C$-terminal half of the protein. Failure of the group $1 \mathrm{mAbs}$ to bind $\mathrm{CP}$ with larger truncations of between 175 (N5) and 210 residues (N6), conservatively placed their binding site between residues 140 and 210 in CP. Meanwhile, group 2 mAbs (4.8E2, 4.10A11, 5.1B2, 5.2F8, 5.4G8 and 5.5A11) were able to detect rCap but none of the $N$-terminally truncated proteins (Table 3 ). This suggested that all mAbs from group 2 bound the $N$-terminal region of the $\mathrm{CP}$, since only the first 35 residues were missing from the smallest $N$-truncation (N1). Similar results were observed when selected group 1 and 2 mAbs were tested against the $N$-terminally truncated recombinant proteins in acetone-fixed transfected cells by IFA (Figure 4).

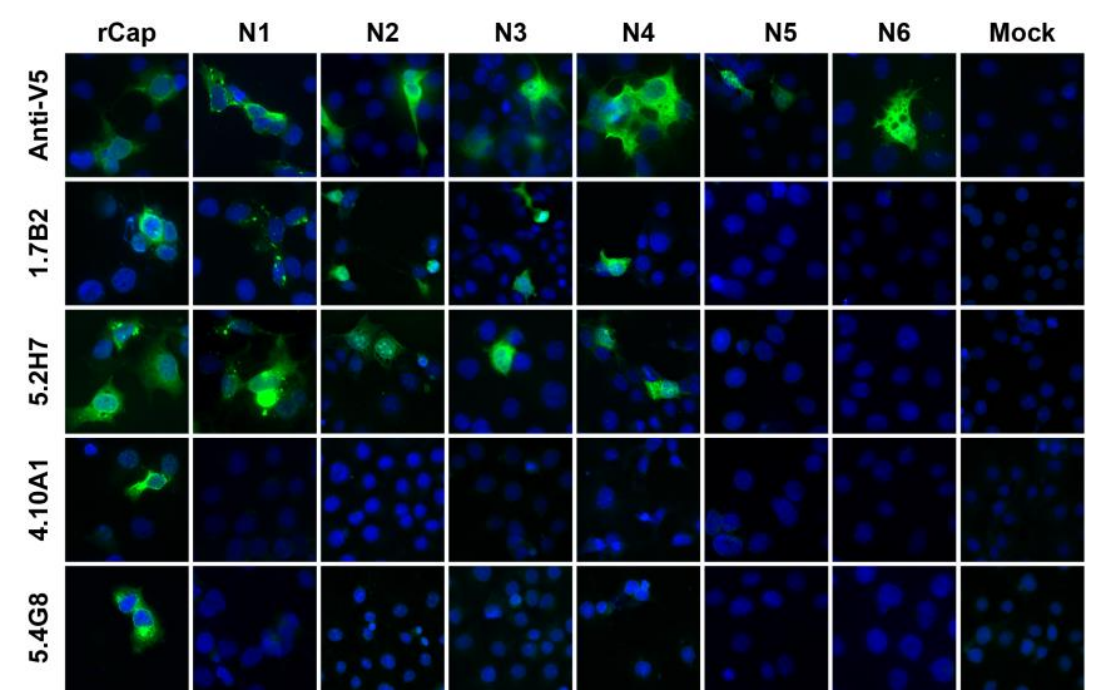

Figure 4. Monoclonal antibody reactivity by Immunofluorescence Assay (IFA) with acetone-fixed monolayers of COS-7L cells transfected with full-length rCap or N-truncated constructs. Cells were probed with respective mAbs before incubation with an anti-mouse Alexa Fluro 488 conjugate (green) and Hoechst 33,342 (blue) for nuclear staining. Two mAbs representing each group were chosen for this experiment: Group 1-1.7B2, 5.2H7; and Group 2-4.10A11, 5.4G8. Images were captured at $400 \times$ or $1000 \times$ magnification. 


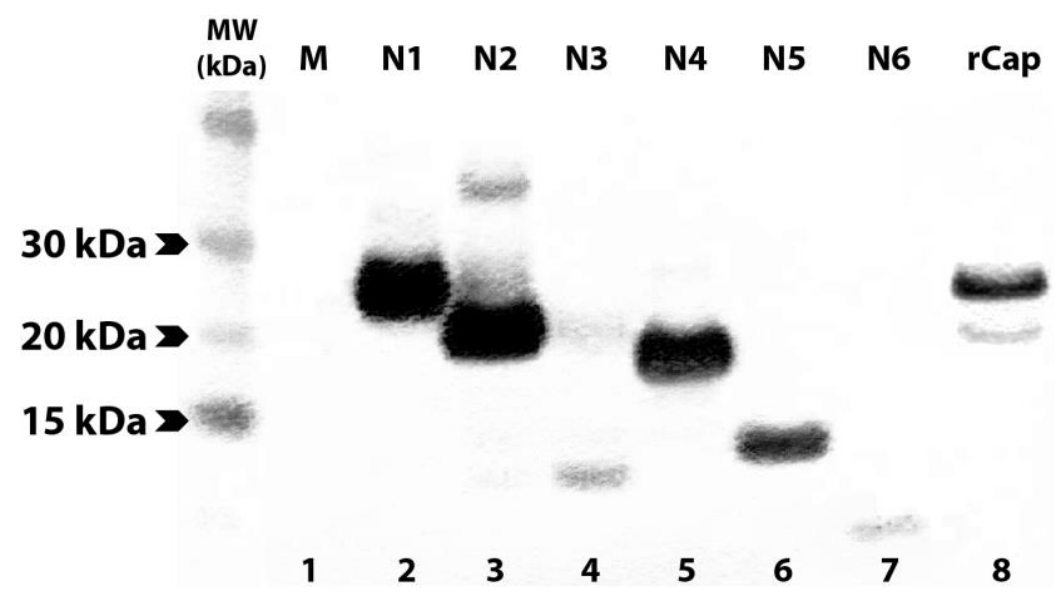

Figure 5. Western blot of recombinant full-length and N-truncated $\mathrm{CP}$ in lysates of transfected cells. Clarified lysates of transfected COS-7L cells were boiled and reduced with DTT prior to immunoblotting with anti-V5 mAb. Lane 1: mock-transfected COS-7L lysate; lanes 2-7: N1-6; and lane 8: full-length rCap.

Table 3. Reactivity of anti-CHIKV mAbs against full-length, $C$ - or $N$-terminally truncated versions of rCap in Western blot.

\begin{tabular}{ccccccccccccccc}
\hline \multirow{2}{*}{ Monoclonal antibody } & Group & \multicolumn{10}{c}{ Reactivity in Western blot } \\
\cline { 2 - 11 } & & FL & N1 & N2 & N3 & N4 & N5 & N6 & C1 & C2 & C3 & C4 & C5 \\
\hline 1.7B2 & 1 & + & + & + & + & + & - & - & - & - & - & - & - \\
$4.1 \mathrm{H} 11$ & 1 & + & + & + & + & + & - & - & - & - & - & - & - \\
$5.2 \mathrm{H} 7$ & 1 & + & + & + & + & + & - & - & - & - & - & - & - \\
$5.5 \mathrm{D} 11$ & 1 & + & + & + & + & + & - & - & - & - & - & - & - \\
$5.5 \mathrm{G} 9$ & 1 & + & + & + & + & + & - & - & - & - & - & - & - \\
$5.1 \mathrm{~B} 12$ & 2 & + & - & - & - & - & - & - & - & - & - & - & - \\
$5.5 \mathrm{~A} 11$ & 2 & + & - & - & - & - & - & - & - & - & - & - & - \\
$4.8 \mathrm{E} 2$ & 2 & + & - & - & - & - & - & - & - & - & - & - & - \\
$4.10 \mathrm{~A} 11$ & 2 & + & - & - & - & - & - & - & - & - & - & - & - \\
$5.2 \mathrm{~F} 8$ & 2 & + & - & - & - & - & - & - & - & - & - & - & - \\
$5.4 \mathrm{G} 8$ & 2 & + & - & - & - & - & - & - & - & - & - & - & - \\
\hline
\end{tabular}

When all mAbs were tested against $C$-terminally truncated forms of $\mathrm{CP}$, none of the antibodies from either group recognized any of the truncated proteins in IFA (Figure 4) or Western blot (Table 3) despite their recognition by the anti-V5 antibody, suggesting that the $C$-terminal region of CP might be required for authentic antigenic structure of $\mathrm{CP}$. This was confirmed by the reactivity of mouse polyclonal anti-CHIKV antibody with rCap and $N$-terminally truncated proteins $(N 1-4)$ in Western blot but none of the $C$-terminally truncated proteins (Figure S3).

\subsection{Group $1 \mathrm{mAbs}$ Bind Native N-terminally Truncated CP in CHIKV Lysates}

IFA and Western blot analysis of $N$-terminally truncated recombinant $\mathrm{CP}$ indicated that group $1 \mathrm{mAbs}$ recognized a region in the $C$-terminal half of the CHIKV CP while group $2 \mathrm{mAbs}$ bound the $N$-terminal 
region. We also observed that, in addition to detecting the rCap in lysates of CHIKV-infected cells $(\sim 35 \mathrm{kDa})$, group $1 \mathrm{mAbs}$ also detected smaller, truncated versions of native $\mathrm{CP}(\mathrm{sCP})$ ranging from $\sim 15-30 \mathrm{kDa}$ (Figure 6A). In contrast, antibodies from group 2 only recognized full-length CP in these lysates (Figure 6B, Figure S4).

To determine the identity of the truncated native versions of $\mathrm{CP}$, capsid proteins were immune-precipitated from $\mathrm{CHIKV}$-infected lysates with protein $\mathrm{G}$ beads coupled to $\mathrm{mAb} 1.7 \mathrm{~B} 2$ (group 1). Resulting pull-downs were resolved on SDS-PAGE and selected Coomassie-stained CPs were analysed by mass spectrometry. These analyses showed that all species of CP recognized by mAb 1.7B2, including the rCap, contained the same $C$-terminal peptide (Figure 7). However, as the CP molecules were truncated, detection of the $N$-terminus region was progressively lesser, with observations that peptides toward the $N$-terminal side of the protein, that were previously identified in larger-sized bands, were missing. No smaller molecules of $\mathrm{CP}$ were precipitated, which was consistent with the binding pattern of 1.7B2 and other group $1 \mathrm{mAbs}$ to $N$-terminally-truncated recombinant CPs; binding to $N 1$ to N4 (35-140 residues removed) but not N5 and N6 (175 and 210 residues removed). Together, these data confirm that the epitopes recognized by $1.7 \mathrm{~B} 2$, and other group $1 \mathrm{mAbs}$, were located between residues 140 and 210 in the $C$-terminal half of CP. Furthermore, the lack of recognition of native CP truncated by 36 or more residues from the $N$-terminus by group $2 \mathrm{mAbs}$, also supports their binding to an $N$-terminal domain — within the first 35 amino acids — of the protein.

A)

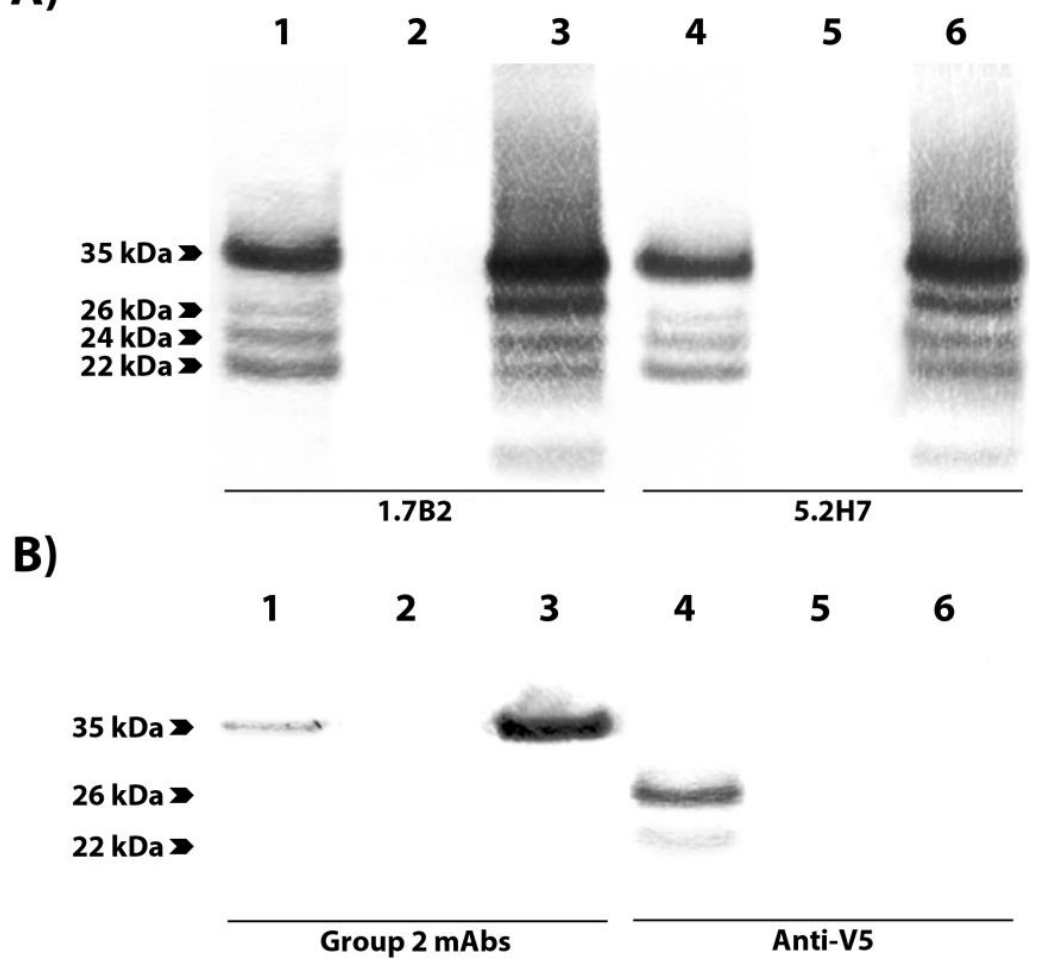

Figure 6. Reactivity of anti-CP mAbs with full length and truncated versions of native and recombinant CP. Reactivity of mAbs 1.7B2 (lanes A1-3), 5.2H7 (lanes A4-6), cocktail of group 2 mAbs (lanes B1-3) and anti-V5 mAb (lanes B4-6) in Western blot against boiled and reduced lysates of COS-7L cells expressing rCap (lanes 1 and 4), mock-transfected COS-7L cells (lanes 2 and 5), and CHIKV-infected C6/36 cells (lanes 3 and 6). 


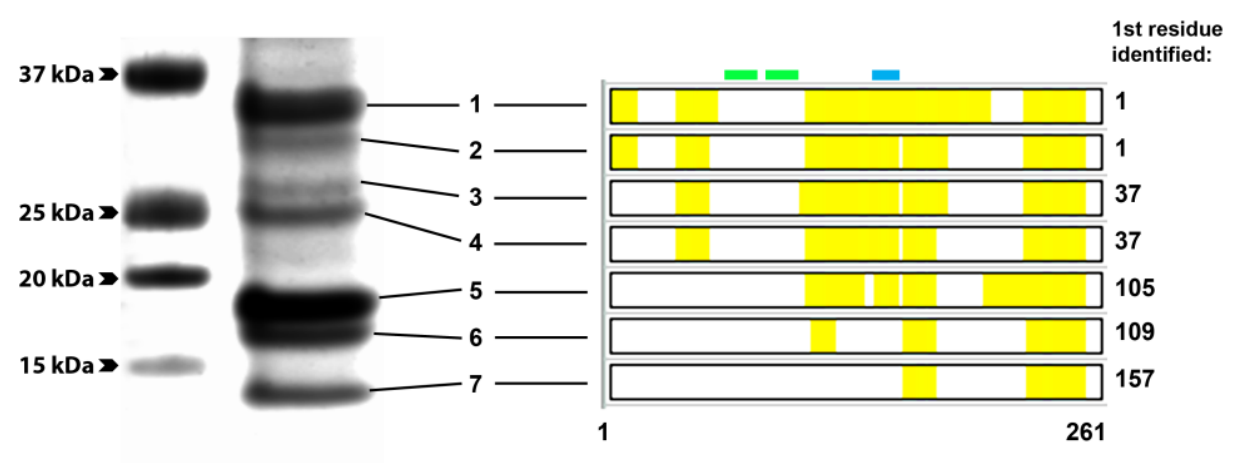

$10 \mathrm{kDa}=$

1)

MEFIPTQTFYNRRYQPRPWTPRPTIQVIRPRPRPQRQAGQLAQLISAVNKLTMRAVPQQKPRRNRKNKKQKQKQQAPQNNTNQKKQP PKKKPAQKKKKPGRRERMCMKIENDCIFEVKHEGKVTGYACLVGDKVMKPAHVKGTIDNADLAKLAFKRSSKYDLECAQIPVHMKSD ASKFTHEKPEGYYNWHHGAVQYSGGRFTIPTGAGKPGDSGRPIFDNKGRVVAIVLGGANEGARTALSVVTWNKDIVTKITPEGAEEW

2)

MEFIPTOTFYNRRYOPRPWTPRPTIOVIRPRPRPOROAGOLAOLISAVNKLTMRAVPOOKPRRNRKNKKOKOKOOAPONNTNOKKOP PKKKPAQKKKKP GRRERMCMKIENDCIFEVKHEGKVTGYACLVGDKVMKPAHVKGTIDNADLAKLAFKRSSKYDLECAQIPVHMKSD ASKFTHEKPEGYYNWHHGAVQYSGGRFT I PTGAGKPGDSGRP I F DNKGRVVAIVLGGANEGARTALSVVTWNKDIVTKITPEGAEEW 3)

MEFIPTOTFYNRRYOPRPWTPRPTIOVIRPRPRPOROAGOLAOLISAVNKLTMRAVPQOKPRRNRKNKKOKQKQQAPQNNTNQKKOP PKKKPAQKKKKPGRRERMCMKIENDCIFEVKHEGKVTGYACLVGDKVMKPAHVKGTIDNADLAKLAFKRSSKYDLECAQIPVHMKSD ASKFTHEKPEGYYNWHHGAVQYSGGRFT I PTGAGKPGDSGRP IFDNKGRVVAIVLGGANEGARTALSVVTWNKDIVTKITPEGAEEW

4)

MEFIPTQTFYNRRYQPRPWTPRPTIQVIRPRPRPQRQAGQLAQLISAVNKLTMRAVPQQKPRRNRKNKKQKQKQQAPQNNTNQKKQP PKKKPAOKKKKPGRRERMCMKIENDCIFEVKHEGKVTGYACLVGDKVMKPAHVKGTIDNADLAKLAFKRSSKYDLECAOIPVHMKSD ASKFTHEKPEGYYNWHHGAVQYSGGRFT I PTGAGKPGDSGRP IFDNKGRVVAIVLGGANEGARTALSVVTWNKDIVTKITPEGAEEW 5)

MEFIPTQTFYNRRYQPRPWTPRPTIQVIRPRPRPQRQAGQLAQLISAVNKLTMRAVPQQKPRRNRKNKKOKQKQQAPQNNTNQKKQP PKKKPAQKKKKPGRRERMCMKIENDCIFEVKHEGKVTGYACLVGDKVMKPAHVKGTIDNADLAKLAFKRSSKYDLECAQIPVHMKSD ASKFTHEKPEGYYNWHHGAVQYSGGRFTIPTGAGKPGDSGRPIFDNKGRVVAIVLGGANEGARTALSVVTWNKDIVTKITPEGAEEW $6)$

MEFIPTQTFYNRRYQPRPWTPRPTIQVIRPRPRPQRQAGQLAQLISAVNKLTMRAVPQQKPRRNRKNKKQKQKQQAPQNNTNQKKQP PKKKPAOKKKKPGRRERMCMKIENDCIFEVKHEGKVTGYACLVGDKVMKPAHVKGT I DNADLAKLAFKRSSKYDLECAOIPVHMKSD ASKFTHEKPEGYYNWHHGAVQYSGGRFT I PTGAGKPGDSGRP I FDNKGRVVAIVLGGANEGARTALSVVTWNKDIVTKITPEGAEEW 7)

MEFIPTQTFYNRRYQPRPWTPRPTIQVIRPRPRPQRQAGQLAQLISAVNKLTMRAVPQQKPRRNRKNKKQKQKQQAPQNNTNQKKQP PKKKPAQKKKKPGRRERMCMKIENDCIFEVKHEGKVTGYACLVGDKVMKPAHVKGTI DNADLAKLAFKRSSKYDLECAQIPVHMKSD ASKETHEKPEGYYNWHHGAVQYSGGRFT I PTGAGKPGDSGRP I FDNKGRVVAIVLGGANEGARTALSVVTWNKDIVTKITPEGAEEW

Figure 7. Coverage of the CHIKV capsid protein by peptides identified via mass spectrometry analysis of different bands excised from SDS-PAGE of boiled and reduced proteins immunoprecipitated by a group $1 \mathrm{mAb}, 1.7 \mathrm{~B} 2$. Indicated in green and blue are the predicted positions of the CHIKV CP NLS and NES, respectively. Sequences for peptides identified within each respective CHIKV CP band (1-7) are bolded and highlighted in yellow.

\subsection{Group $1 \mathrm{mAbs}$ Target a Series of Overlapping Epitopes on CP}

To further define the binding sites of the mAbs from group 1, and determine the topology of their epitopes in the $C$-terminal half of $\mathrm{CP}$, representative group 1 antibodies were tested in a competitive binding assay against one another using ELISA. Three of the five mAbs in this group (1.7B2, 4.1H11 and 5.2H7) were successfully biotinylated and subsequently assessed for competition against saturating concentrations of each of the five unlabelled mAbs to establish the degree of inhibition exhibited for each pairing. MAbs 1.7B2 and 4.1H11 showed complete two-way inhibition with each other indicating they bind to the same or highly adjacent epitopes (Figure 8). Partial two-way inhibition of both these mAbs with mAb 5.2H7 was also observed, suggesting that the epitope recognized by $5.2 \mathrm{H} 7$ is slightly 
different to the former pair but in the same spatial domain. The partial one-way inhibition of 5.2H7 by the unlabelled mAbs 5.5D11 and 5.5G9, but not by 1.7B2 and 4.1H11, suggests a continuum of overlapping epitopes (Figure 9). The competitive binding result also confirms that these antibodies bind to the same region of the $\mathrm{CP}$.

\section{Competitive Binding Assay}

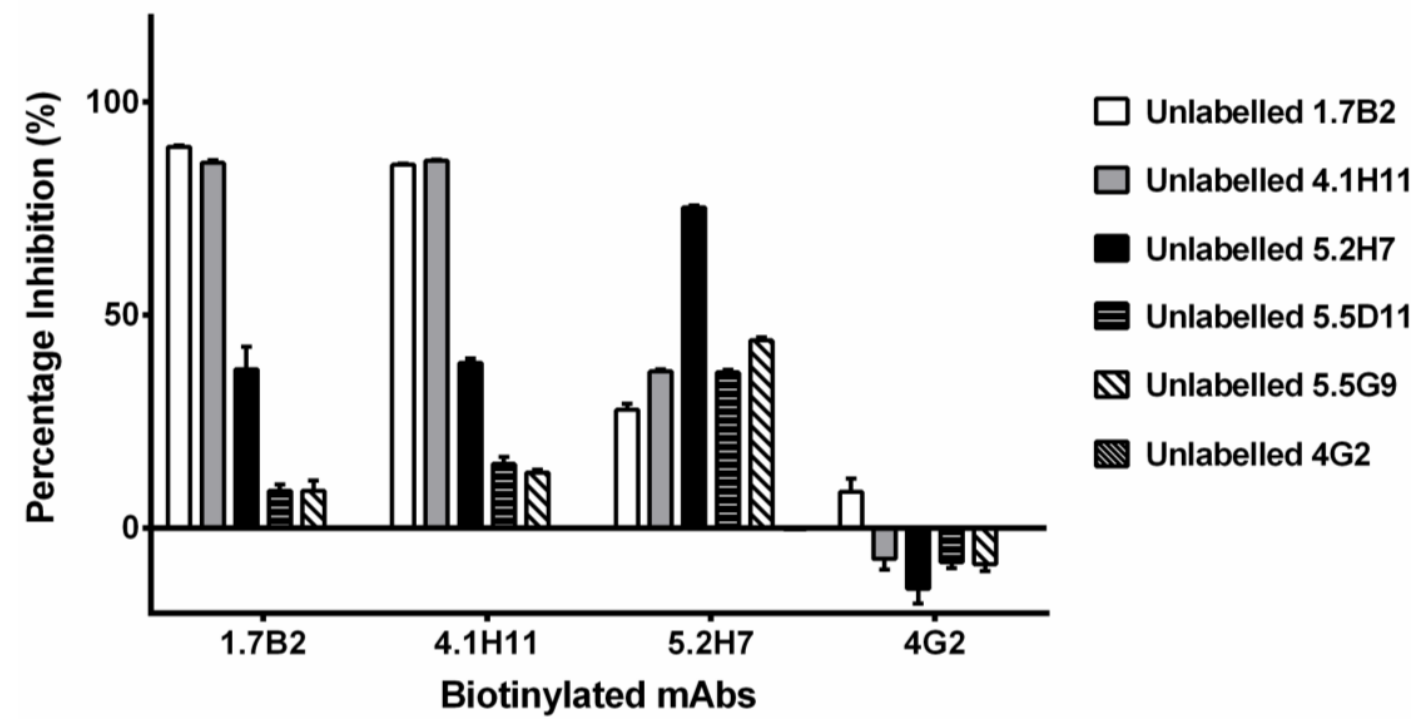

Figure 8. Competitive binding profiles of CHIKV CP-specific mAbs in ELISA. Antigens in

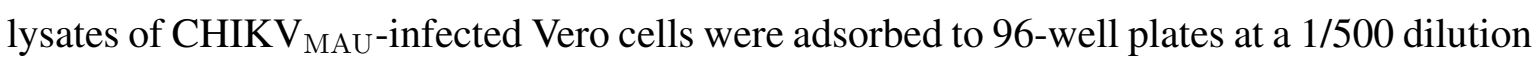
prior to incubation with a saturating dilution of purified, unlabelled anti-CP mAbs. Without washing, non-saturating dilutions of biotinylated mAbs were then added as 'competitor' antibodies to respective wells. The mean absorbance reading $\left(\mathrm{OD}_{405 \mathrm{~nm}}\right)$ of four replicates were plotted with bars showing standard error of mean (SEM). 4G2 is a control mAb specific to the E protein of flaviviruses. Assay was optimized to obtain complete inhibition of each biotinylated $\mathrm{mAb}$ by its homologous unlabelled competitor.

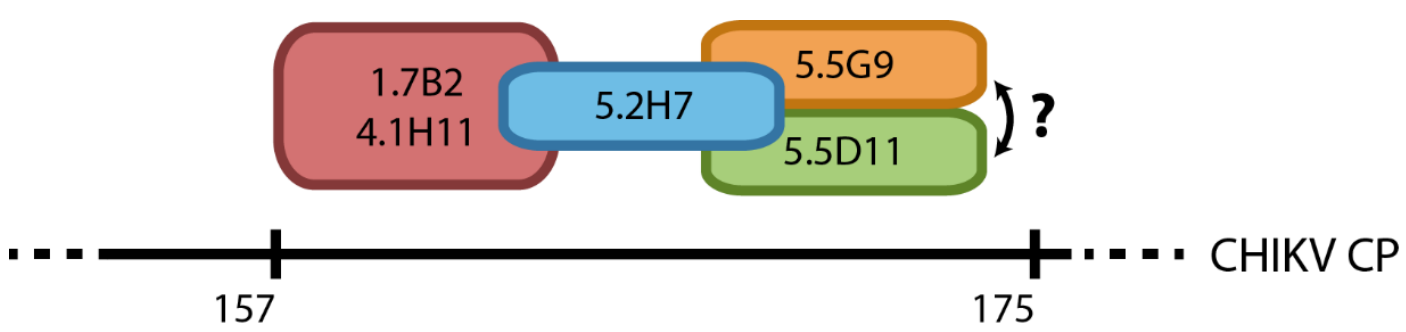

Figure 9. Schematic representation of proposed spatial relationship of epitopes recognized by group 1 anti-CP mAbs. Antibodies in the same coloured circle illustrates two-way inhibition, with overlaps representing one-way inhibition amongst mAbs tested. While it is safe to assume that the sequence of overlapping should be fairly accurate since the group $1 \mathrm{mAbs}$ do recognize linear epitopes, the order of epitopes might be inversed. Furthermore, it is highly likely that mAbs bind from residues $157-175$, however, a more conservative estimate would be from position 140-210. 


\section{Discussion}

In this study, we used a series of truncated recombinant proteins to map the binding sites of a panel of CHIKV CP-specific mAbs produced in a previous study [34]. The binding patterns of the mAbs to recombinant truncated CPs in Western blot and IFA allowed us to deduce that these antibodies bound two regions of CP; one domain in the $C$-terminal half of the protein between residues 140 and 210 (group $1 \mathrm{mAbs}$ ), and a second putative domain likely located within the first 35 amino acids of the $N$-terminus of CP (group $2 \mathrm{mAbs)}$ ). Mass spectrometry analysis of native, $N$-terminally truncated CP species in CHIKV-infected cell lysates that were recognized by group 1 but not group 2 mAbs, further supported the proposed location of the two binding domains of these mAbs. The binding of all group $1 \mathrm{mAbs}$ to a defined region between residues 140 and 210 in the $C$-terminal half of $\mathrm{CP}$ was further indicated by the competitive binding experiments, demonstrating that these mAbs recognized a series of overlapping epitopes representing a continuum of binding sites. The proposed spatial relationship of epitopes recognized by the group $1 \mathrm{mAbs}$ is schematically presented in Figure 9. The putative binding domain for the group 2 mAbs was indicated to be in the first 35 residues due to their inability to bind the smallest N-truncation in IFA and Western blot, and a lack of reactivity of these mAbs to native species of $N$-truncated CHIKV CP, as revealed by the mass spectrometry data. However, without direct evidence of group $2 \mathrm{mAbs}$ binding to this region, the location of this domain requires further confirmation.

Another interesting finding to emerge from this study was the presence of truncated CHIKV CPs in preparations of both native and recombinantly-expressed protein. Truncated fragments of CHIKV CP, displaying sizes similar to those observed in this study, have previously been identified in cells expressing recombinant CHIKV CP from a baculovirus vector, as well as cells infected with a recombinant measles vaccine expressing CHIKV virus-like particles [36,37]. This uncharacterized minor product of CP has also been documented in other alphaviruses such as WEEV and SINV [38-40]. Based on the observations made and data obtained in this study, a schematic of the different sized CP bands derived from molecular weight analysis of $\mathrm{CP}$ from both crude lysates of CHIKV-infected C6/36 cells and recombinantly expressed versions, was constructed (Figure 10). This suggests that the $N$-terminally-truncated $\mathrm{sCP}$ is approximately $10-11 \mathrm{kDa}$ smaller than its full-sized counterpart and is truncated by $\sim 100$ residues from the $N$-terminus. This was confirmed by successful retention of the $C$-terminally inserted V5-His tag and the mass spectrometry analysis that the $N$-terminal peptide identified in the major native species of sCP in CHIKV-infected cell lysates began with the methionine at position 105 in CHIKV CP. This also corresponds with a predicted alternate translation initiation site at the third AUG of the 26S RNA in the alphavirus structural polyprotein, previously observed in a SINV mutant [41].

Studies with New World alphaviruses (e.g., Western/Eastern/Venezuelan equine encephalitis viruses) have shown that CP mediates shutdown of host cell transcription [19]. In contrast, the viral nsP2, not CP, appears to mediate this role in the Old World alphaviruses (e.g., Sindbis virus, Semliki Forest, Ross River virus) [42]. However, there is no published evidence that CHIKV, considered an Old World alphavirus, also uses the latter mechanism. Old World alphaviruses have evolved a downstream loop (DLP) in the 26S subgenomic RNA that stalls the ribosome at the first AUG, allowing acquisition of specific initiation factors and high level translation of viral protein in an environment where host gene translation in the infected vertebrate cell is suppressed due to eukaryotic initiation factor 2 alpha (eIF-2 $\alpha$ ) phosphorylation. 
The lack of a DLP-like structure in CHIKV is consistent with a recent report that CHIKV nsP4 prevents eIF- $2 \alpha$ phosphorylation during infection and negates the need for a DLP enhancer and ribosome stalling at the first AUG. These findings also fit with our observations that an $N$-terminally truncated form of $\mathrm{CP}$ is produced in the $\mathrm{CHIKV}$-infected cell, consistent with leaking ribosome scanning [43] and alternative translation initiation from the conserved 3rd AUG in the 26S subgenomic RNA (codon 105 in the capsid gene).

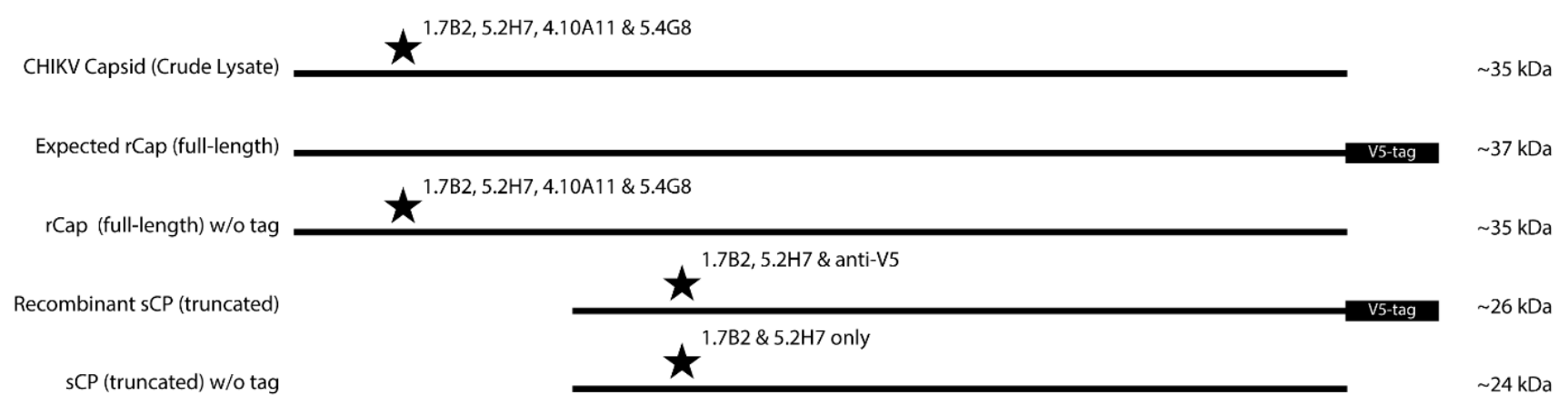

Figure 10. Schematic representation of different sizes of CP observed in Western blot. Stars represents the mAbs that are reactive toward that particular protein band. To obtain sizes of protein bands, a calibration curve was constructed by semi-logarithmically plotting the relative mobility values of the molecular weight standards against their known molecular weights. The relative mobility of each target protein was then utilized to estimate their molecular weight. sCP is truncated at the $N$-terminus.

Our initial findings that all the anti-CP mAbs included in this study recognized reduced and carboxymethylated antigens in Western blot, indicated they bound to linear or continuous epitopes independent of tertiary structure. Thus, it was surprising that attempts to further define the binding sites of these antibodies using a series of 20-mer synthetic peptides with 10-mer overlaps covering the entire CHIKV CP were unsuccessful. None of the mAbs showed any reactivity towards the peptides when adsorbed to the solid phase in ELISA, bound onto nitrocellulose membranes in dot blot, or when presented on microspheres in a Luminex-based assay. The successful recognition of control peptides, synthesized in the same batch, by their corresponding mAbs in each assay indicated that incorrect synthesis was not likely to be the problem. This suggested that the epitopes on CHIKV CP required additional structures for $\mathrm{mAb}$ recognition, potentially post-translational modifications such as phosphorylation or glycosylation, as described in previous studies $[44,45]$. The $\mathrm{CP}$ of alphaviruses are known not to harbour any $N$-linked glycosylation, which was previously confirmed by endoglycosidase digestion [34]. However, eight potential sites of phosphorylation have been predicted in CHIKV CP based on its amino acid sequence, with two potentially phosphorylated residues at positions 8 and 20, both in the proposed binding region of group $2 \mathrm{mAbs}$, and one at residue 158 in the putative binding domain of group $1 \mathrm{mAbs}$ (Figure 3).

The lack of reaction of all $\mathrm{mAbs}$ and polyclonal antisera to $C$-terminally truncated recombinant $\mathrm{CP}$, despite their clear detection by anti-V5 in Western blot and IFA, was also unexpected considering the apparent linear nature of their epitopes. This suggests that the $C$-terminal residues may be crucial to the antigenic structure of CHIKV CP, either by facilitating phosphorylation of residues in the binding sites 
as referred to above, or by stabilizing the overall structure of $\mathrm{CP}$ and exposing these epitopes on the surface of the protein, allowing access for antibody binding. Both of these hypotheses fit well with the data obtained in this study, including the failure of the antibodies to recognize the synthetic peptides; the 20-mer peptides predicted to contain the putative binding sites (peptides no. 1-4 for group 2 mAbs; no. 15-18 for group $1 \mathrm{mAbs}$ ) would also lack the hypothesized $C$-terminal peptides of CP. Future studies to resolve this question and further define the binding sites of the anti-CP mAbs, could include the re-construction of rCap with variable internal deletions and the retention of the $C$-terminal residues.

\section{Conclusions}

In summary, we have mapped the binding sites of a panel of anti-CHIKV CP mAbs to two proposed domains. Group $2 \mathrm{mAbs}$ recognize a putative domain between residues 1-35, while group $1 \mathrm{mAbs}$ bind a region between residues 140-210; the latter targeting a series of overlapping epitopes. We also provided evidence that the $C$-terminus of $\mathrm{CP}$ is required for the authentic antigenic structure of the protein - and thus antibody binding - and have identified a smaller species of CP in CHIKV-infected cells that may represent an alternative translation product of the viral 26S RNA. Our epitope mapping studies have identified novel structural properties of the CHIKV CP and characterized useful reagents for their further investigation. A better understanding of the structure of $\mathrm{CP}$ will provide valuable insight into the multifunctional role of this protein in CHIKV replication, as well as that of numerous other alphaviruses.

\section{Acknowledgements}

Access to proteomic infrastructure in the QIMR Berghofer Protein Discovery Centre was made possible by funding from Bioplatforms Australia and the Queensland State Government provided through the Australian Government National Collaborative Infrastructure Scheme (NCRIS) and Education Investment Fund (EIF). Lucas Yuan Hao Goh was supported by the University of Queensland international research tuition award (UQIRTA) from the UQ Graduate School, the University of Queensland, and the ANZ Trustees scholarship for medical research, Queensland.

\section{Author Contributions}

Lucas Y. H. Goh, Jody Hobson-Peters, Jeff J. Gorman and Roy A. Hall conceived and designed the experiments; Lucas Y. H. Goh, Marcus L. Hastie, Jody Hobson-Peters, Natalie A. Prow, Kelly Baker, Thisun B. H. Piyasena, Carmel T. Taylor, Ashok Rana performed the experiments; Lucas Y. H. Goh, Jody Hobson-Peters, Marcus L. Hastie and Roy A. Hall analyzed the data; Lucas Y. H. Goh wrote the paper; Roy A. Hall and Jody Hobson-Peters edited the paper. All authors contributed to the preparation of the manuscript and have approved of the submitted version. 


\section{Conflicts of Interest}

The authors declare no conflict of interest.

\section{References}

1. Suhrbier, A.; Jaffar-Bandjee, M.C.; Gasque, P. Arthritogenic alphaviruses-An overview. Nat. Rev. Rheumatol. 2012, 8, 420-429. [CrossRef] [PubMed]

2. Tesh, R.B. Arthritides caused by mosquito-borne viruses. Annu. Rev. Med. 1982, 33, 31-40. [CrossRef] [PubMed]

3. Staples, J.E.; Breiman, R.F.; Powers, A.M. Chikungunya fever: An epidemiological review of a re-emerging infectious disease. Clin. Infect. Dis. 2009, 49, 942-948. [CrossRef] [PubMed]

4. Borgherini, G.; Poubeau, P.; Staikowsky, F.; Lory, M.; Le Moullec, N.; Becquart, J.P.; Wengling, C.; Michault, A.; Paganin, F. Outbreak of chikungunya on Reunion Island: Early clinical and laboratory features in 157 adult patients. Clin. Infect. Dis. 2007, 44, 1401-1407. [CrossRef] [PubMed]

5. Renault, P.; Solet, J.L.; Sissoko, D.; Balleydier, E.; Larrieu, S.; Filleul, L.; Lassalle, C.; Thiria, J.; Rachou, E.; de Valk, H.; et al. A major epidemic of chikungunya virus infection on Reunion Island, France, 2005-2006. Am. J. Trop. Med. Hyg. 2007, 77, 727-731. [PubMed]

6. Grandadam, M.; Caro, V.; Plumet, S.; Thiberge, J.M.; Souares, Y.; Failloux, A.B.; Tolou, H.J.; Budelot, M.; Cosserat, D.; Leparc-Goffart, I.; et al. Chikungunya virus, southeastern France. Emerg. Infect. Dis. 2011, 17, 910-913. [CrossRef] [PubMed]

7. Rezza, G.; Nicoletti, L.; Angelini, R.; Romi, R.; Finarelli, A.C.; Panning, M.; Cordioli, P.; Fortuna, C.; Boros, S.; Magurano, F.; et al. Infection with Chikungunya virus in Italy: An outbreak in a temperate region. Lancet 2007, 370, 1840-1846. [CrossRef] [PubMed]

8. Lam, S.K.; Chua, K.B.; Hooi, P.S.; Rahimah, M.A.; Kumari, S.; Tharmaratnam, M.; Chuah, S.K.; Smith, D.W.; Sampson, I.A. Chikungunya infection-An emerging disease in Malaysia. Southeast Asian J. Trop. Med. Public Health 2001, 32, 447-451. [PubMed]

9. Munasinghe, D.R.; Amarasekera, P.J.; Fernando, C.F. An epidemic of dengue-like fever in Ceylon (chikungunya-A clinical and haematological study. Ceylon Med. J. 1966, 11, 129-142. [PubMed]

10. Horwood, P.; Bande, G.; Dagina, R.; Guillaumot, L.; Aaskov, J.; Pavlin, B. The threat of chikungunya in Oceania. West. Pac. Surveill. Response J. 2013, 4, 8-10. [CrossRef] [PubMed]

11. Van Bortel, W.; Dorleans, F.; Rosine, J.; Blateau, A.; Rousset, D.; Matheus, S.; Leparc-Goffart, I.; Flusin, O.; Prat, C.; Cesaire, R.; et al. Chikungunya outbreak in the Caribbean region, December 2013 to March 2014, and the significance for Europe. Euro Surveill. 2014, 19. [CrossRef]

12. Jaffar-Bandjee, M.C.; Ramful, D.; Gauzere, B.A.; Hoarau, J.J.; Krejbich-Trotot, P.; Robin, S.; Ribera, A.; Selambarom, J.; Gasque, P. Emergence and clinical insights into the pathology of Chikungunya virus infection. Expert Rev. Anti Infect. Ther. 2010, 8, 987-996. [CrossRef] [PubMed]

13. Tandale, B.V.; Sathe, P.S.; Arankalle, V.A.; Wadia, R.S.; Kulkarni, R.; Shah, S.V.; Shah, S.K.; Sheth, J.K.; Sudeep, A.B.; Tripathy, A.S.; et al. Systemic involvements and fatalities during Chikungunya epidemic in India, 2006. J. Clin. Virol. 2009, 46, 145-149. [CrossRef] [PubMed] 
14. Economopoulou, A.; Dominguez, M.; Helynck, B.; Sissoko, D.; Wichmann, O.; Quenel, P.; Germonneau, P.; Quatresous, I. Atypical Chikungunya virus infections: Clinical manifestations, mortality and risk factors for severe disease during the 2005-2006 outbreak on Reunion. Epidemiol. Infect. 2009, 137, 534-541. [CrossRef] [PubMed]

15. Mavalankar, D.; Shastri, P.; Bandyopadhyay, T.; Parmar, J.; Ramani, K.V. Increased mortality rate associated with Chikungunya epidemic, Ahmedabad, India. Emerg. Infect. Dis. 2008, 14, 412-415. [CrossRef] [PubMed]

16. Strauss, J.H.; Strauss, E.G. The alphaviruses: Gene expression, replication, and evolution. Microbiol. Rev. 1994, 58, 491-562. [PubMed]

17. Choi, H.K.; Tong, L.; Minor, W.; Dumas, P.; Boege, U.; Rossmann, M.G.; Wengler, G. Structure of Sindbis virus core protein reveals a chymotrypsin-like serine proteinase and the organization of the virion. Nature 1991, 354, 37-43. [CrossRef] [PubMed]

18. Aguilar, P.V.; Weaver, S.C.; Basler, C.F. Capsid protein of eastern equine encephalitis virus inhibits host cell gene expression. J. Virol. 2007, 81, 3866-3876. [CrossRef] [PubMed]

19. Elgizoli, M.; Dai, Y.; Kempf, C.; Koblet, H.; Michel, M.R. Semliki Forest virus capsid protein acts as a pleiotropic regulator of host cellular protein synthesis. J. Virol. 1989, 63, 2921-2928. [PubMed]

20. Hong, E.M.; Perera, R.; Kuhn, R.J. Alphavirus capsid protein helix I controls a checkpoint in nucleocapsid core assembly. J. Virol. 2006, 80, 8848-8855. [CrossRef] [PubMed]

21. Thomas, S.; Rai, J.; John, L.; Schaefer, S.; Putzer, B.M.; Herchenroder, O. Chikungunya virus capsid protein contains nuclear import and export signals. Virol. J. 2013, 10, 269. [CrossRef] [PubMed]

22. Favre, D.; Studer, E.; Michel, M.R. Two nucleolar targeting signals present in the $N$-terminal part of Semliki Forest virus capsid protein. Arch. Virol. 1994, 137, 149-155. [CrossRef] [PubMed]

23. Jakob, R. Nucleolar accumulation of Semliki Forest virus nucleocapsid C protein: Influence of metabolic status, cytoskeleton and receptors. J. Med. Microbiol. 1994, 40, 389-392. [CrossRef] [PubMed]

24. Nigg, E.A.; Baeuerle, P.A.; Luhrmann, R. Nuclear import-export: In search of signals and mechanisms. Cell 1991, 66, 15-22. [CrossRef]

25. Clark, D.C.; Lobigs, M.; Lee, E.; Howard, M.J.; Clark, K.; Blitvich, B.J.; Hall, R.A. In situ reactions of monoclonal antibodies with a viable mutant of Murray Valley encephalitis virus reveal an absence of dimeric NS1 protein. J. Gen. Virol. 2007, 88, 1175-1183. [CrossRef] [PubMed]

26. Hobson-Peters, J.; Toye, P.; Sanchez, M.D.; Bossart, K.N.; Wang, L.F.; Clark, D.C.; Cheah, W.Y.; Hall, R.A. A glycosylated peptide in the West Nile virus envelope protein is immunogenic during equine infection. J. Gen. Virol. 2008, 89, 3063-3072. [CrossRef] [PubMed]

27. Setoh, Y.X.; Hobson-Peters, J.; Prow, N.A.; Young, P.R.; Hall, R.A. Expression of recombinant West Nile virus prM protein fused to an affinity tag for use as a diagnostic antigen. J. Virol. Methods 2011, 175, 20-27. [CrossRef] [PubMed] 
28. Goh, L.Y.; Hobson-Peters, J.; Prow, N.A.; Gardner, J.; Bielefeldt-Ohmann, H.; Pyke, A.T.; Suhrbier, A.; Hall, R.A. Neutralizing monoclonal antibodies to the E2 protein of chikungunya virus protects against disease in a mouse model. Clin. Immunol. 2013, 149, 487-497. [CrossRef] [PubMed]

29. Hall, R.A.; Tan, S.E.; Selisko, B.; Slade, R.; Hobson-Peters, J.; Canard, B.; Hughes, M.; Leung, J.Y.; Balmori-Melian, E.; Hall-Mendelin, S.; et al. Monoclonal antibodies to the West Nile virus NS5 protein map to linear and conformational epitopes in the methyltransferase and polymerase domains. J. Gen. Virol. 2009, 90, 2912-2922. [CrossRef] [PubMed]

30. Hobson-Peters, J.; Toye, P. A whole-blood homogeneous assay for the multiplex detection of the factor V G1691A and the prothrombin G20210A mutations. Mol. Cell. Probes 2005, 19, 290-297. [CrossRef] [PubMed]

31. Hastie, M.L.; Headlam, M.J.; Patel, N.B.; Bukreyev, A.A.; Buchholz, U.J.; Dave, K.A.; Norris, E.L.; Wright, C.L.; Spann, K.M.; Collins, P.L.; et al. The human respiratory syncytial virus nonstructural protein 1 regulates type I and type II interferon pathways. Mol. Cell. Proteomics 2012, 11, 108-127. [CrossRef] [PubMed]

32. Searle, B.C. Scaffold: A bioinformatic tool for validating MS/MS-based proteomic studies. Proteomics 2010, 10, 1265-1269. [CrossRef] [PubMed]

33. Keller, A.; Nesvizhskii, A.I.; Kolker, E.; Aebersold, R. Empirical statistical model to estimate the accuracy of peptide identifications made by MS/MS and database search. Anal. Chem. 2002, 74, 5383-5392. [CrossRef] [PubMed]

34. Goh, L.Y.; Hobson-Peters, J.; Prow, N.A.; Gardner, J.; Bielefeldt-Ohmann, H.; Suhrbier, A.; Hall, R.A. Monoclonal antibodies specific for the capsid protein of chikungunya virus suitable for multiple applications. J. Gen. Virol. 2015, 96, 507-512. [CrossRef] [PubMed]

35. Blom, N.; Gammeltoft, S.; Brunak, S. Sequence- and structure-based prediction of eukaryotic protein phosphorylation sites. J. Mol. Biol. 1999, 294, 1351-1362. [CrossRef] [PubMed]

36. Brandler, S.; Ruffie, C.; Combredet, C.; Brault, J.B.; Najburg, V.; Prevost, M.C.; Habel, A.; Tauber, E.; Despres, P.; Tangy, F. A recombinant measles vaccine expressing chikungunya virus-like particles is strongly immunogenic and protects mice from lethal challenge with chikungunya virus. Vaccine 2013, 31, 3718-3725. [CrossRef] [PubMed]

37. Cho, B.; Kim, J.; Cho, J.E.; Jeon, B.Y.; Park, S. Expression of the capsid protein of Chikungunya virus in a baculovirus for serodiagnosis of Chikungunya disease. J. Virol. Methods 2008, 154, 154-159. [CrossRef] [PubMed]

38. Bell, J.R.; Bond, M.W.; Hunkapiller, M.W.; Strauss, E.G.; Strauss, J.H.; Yamamoto, K.; Simizu, B. Structural proteins of Western equine encephalitis virus: Amino acid compositions and $N$-terminal sequences. J. Virol. 1983, 45, 708-714. [PubMed]

39. Choi, H.K.; Lee, S.; Zhang, Y.P.; McKinney, B.R.; Wengler, G.; Rossmann, M.G.; Kuhn, R.J. Structural analysis of Sindbis virus capsid mutants involving assembly and catalysis. J. Mol. Biol. 1996, 262, 151-167. [CrossRef] [PubMed]

40. Ishida, I.; Simizu, B. Evidence for the presence of the minor capsid protein of Western equine encephalitis virus. Arch. Virol. 1981, 67, 159-164. [CrossRef] [PubMed] 
41. Ventoso, I.; Sanz, M.A.; Molina, S.; Berlanga, J.J.; Carrasco, L.; Esteban, M. Translational resistance of late alphavirus mRNA to eIF2alpha phosphorylation: A strategy to overcome the antiviral effect of protein kinase PKR. Genes Dev. 2006, 20, 87-100. [CrossRef] [PubMed]

42. Kuhn, R. The Togaviruses (Chapter 23). In Fields Virology, 6th ed.; Lippencott Williams and Wilkins: Philadelphia, PA, USA, 2013.

43. Firth, A.E.; Brierley, I. Non-canonical translation in RNA viruses. J. Gen. Virol. 2012, 93, 1385-1409. [CrossRef] [PubMed]

44. Glenney, J.R., Jr.; Zokas, L.; Kamps, M.P. Monoclonal antibodies to phosphotyrosine. J. Immunol. Methods 1988, 109, 277-285. [CrossRef]

45. Kehoe, J.W.; Velappan, N.; Walbolt, M.; Rasmussen, J.; King, D.; Lou, J.; Knopp, K.; Pavlik, P.; Marks, J.D.; Bertozzi, C.R.; et al. Using phage display to select antibodies recognizing post-translational modifications independently of sequence context. Mol. Cell. Proteomics 2006, 5, 2350-2363. [CrossRef] [PubMed]

(C) 2015 by the authors; licensee MDPI, Basel, Switzerland. This article is an open access article distributed under the terms and conditions of the Creative Commons Attribution license (http://creativecommons.org/licenses/by/4.0/). 